\title{
DIFFERENT DOSES OF EXOGENOUS SURFACTANT FOR TREATMENT OF MECONIUM ASPIRATION SYNDROME IN NEWBORN RABBITS
}

\author{
João Cesar Lyra, Renata S. Mascaretti, Alexander Roberto Precioso, Chang Yin \\ Chia, Maria Tereza Zulini da Costa, Flávio Adolfo Costa Vaz, Yassuhiko Okay, \\ and Celso Moura Rebello
}

LYRA JC et al. Different doses of exogenous surfactant for treatment of meconium aspiration syndrome in newborn rabbits. Rev. Hosp. Clín. Fac. Med. S. Paulo 58(3):104-112, 2004.

OBJECTIVE: To evaluate the effects of 2 different doses of exogenous surfactant on pulmonary mechanics and on the regularity of pulmonary parenchyma inflation in newborn rabbits.

METHOD: Newborn rabbits were submitted to tracheostomy and randomized into 4 study groups: the Control group did not receive any material inside the trachea; the MEC group was instilled with meconium, without surfactant treatment; the S100 and S200 groups were instilled with meconium and were treated with 100 and $200 \mathrm{mg} / \mathrm{kg}$ of exogenous surfactant (produced by Instituto Butantan) respectively. Animals from the 4 groups were mechanically ventilated during a 25-minute period. Dynamic compliance, ventilatory pressure, tidal volume, and maximum lung volume (P-V curve) were evaluated. Histological analysis was conducted using the mean linear intercept (Lm), and the lung tissue distortion index (SDI) was derived from the standard deviation of the means of the Lm. One-way analysis of variance was used with a $=0.05$.

RESULTS: After 25 minutes of ventilation, dynamic compliance (mL/cm H $\mathrm{H}_{2} \mathrm{O} \mathrm{kg}$ ) was $0.87 \pm 0.07$ (Control); $0.49 \pm$ 0.04 (MEC*); $0.67 \pm 0.06(\mathrm{~S} 100)$; and $0.67 \pm 0.08(\mathrm{~S} 200)$, and ventilatory pressure $\left(\mathrm{cm} \mathrm{H}_{2} \mathrm{O}\right)$ was $9.0 \pm 0.9(\mathrm{Control}) ; 16.5 \pm$ 1.7 (MEC*); $12.4 \pm 1.1(\mathrm{~S} 100)$; and $12.1 \pm 1.5(\mathrm{~S} 200)$. Both treated groups had lower Lm values and more homogeneity in the lung parenchyma compared to the MEC group: SDI = $7.5 \pm 1.9$ (Control); $11.3 \pm 2.5$ (MEC*), $5.8 \pm 1.9$ (S100); and 6.7 \pm 1.7 (S200) $(* P<0.05$ versus all the other groups).

CONCLUSIONS: Animals treated with surfactant showed significant improvement in pulmonary mechanics and more regularity of the lung parenchyma in comparison to untreated animals. There was no difference in results after treatment with either of the doses used.

KEY WORDS: Meconium. Surfactant inactivation; Neonate; Newborn animals; Pulmonary mechanics.

Meconium aspiration syndrome (MAS) is characterized by respiratory distress in term newborns (NB) that experience intra-uterine or immediately postdelivery meconium elimination, together with specific radiological findings. Despite the several available therapeutic proposals, MAS still remains an important cause of mortality in this group of patients, with rates that vary from $4 \%$ to $37 \%$ (median of $12 \%) .^{2-4}$
The aspirated meconium initially causes airway obstruction and an increase in pulmonary resistance. Subse-

From the Department of Pediatrics, School of Medicine of Botucatu, State University of São Paulo (UNESP); Department of Pediatrics, Hospital das Clínicas, Faculty of Medicine, University of São Paulo and University Hospital, University of São Paulo (USP) - São Paulo/SP, Brazil.

E-mail: jc.lyra@uol.com.br Received for publication on September 17, 2003 quently, the presence of this substance inside the alveoli provokes an intense inflammatory response, with a polymorphonuclear and macrophage leukocyte accumulation, pulmonary edema, and chemical mediator release, causing a chemical pneumonitis. ${ }^{3,5} \mathrm{Ad}-$ ditionally, several experimental studies have demonstrated that the presence of meconium in the distal airways may cause an abnormality in surfactant function as a result of its inhi- 
bition or alteration of its composition, leading to reduction in lung compliance and functional residual capacity, atelectasis, and hypoxia. Despite these findings, the precise mechanism of action has not been completely clarified. ${ }^{6-9}$

According to in vitro and in vivo research models, this inhibitory effect on surfactant function is due to alterations in the surfactant monolayer, the properties of which are modified as a consequence of the infiltration of fatty acid molecules into its interior or as a consequence of lysophosphatidylcholine production from the phospholipid of meconium. This infiltration results in perforations in the cellular membrane of the type II pneumocytes, causing asymmetry of the monolayer. ${ }^{10}$ The reduction of surfactant protein (SP) -A and SP-B levels and a decreased number of phospholipid when the meconium is added to the surfactant has been also demonstrated $^{7}$. The presence of hemorrhage, edema, inflammatory cells, and chemical mediators inside the alveolus also contributes to the inactivation of the surfactant observed in MAS. ${ }^{11-13}$

During the 1990s, several experimental studies demonstrated the benefits of rescue therapy with exogenous surfactant in the treatment of MAS in animal models, with a significant improvement of dynamic pulmonary compliance and ventilatory pressure, decreased need for oxygen, better pulmonary aeration, decreased formation of hyaline membranes, decreased intraalveolar edema, and reduced neutrophil influx into the intra-alveolar spaces after treatment with exogenous surfactant. ${ }^{10,13,14,15,16}$

On the other hand, a number of controlled clinical studies evaluating the use of exogenous surfactant for MAS treatment, most involving a small number of patients, produced conflicting results. ${ }^{14,17-19}$

Considering the complex patho- physiology involved with MAS and the divergence between experimental and clinical results, doubts remain regarding the doses, the administration time, interval, and type of surfactant to be used with rescue therapy.

The purpose of the present study was to evaluate the effects of 2 different doses of a low-cost surfactant produced with Brazilian technology on the respiratory mechanics and morphological pulmonary pattern of newborn rabbits with MAS.

\section{MATERIALS AND METHOD}

\section{Meconium preparation}

MAS was induced in newborn rabbits through endotracheal administration of human meconium, at a $65 \mathrm{mg} /$ $\mathrm{mL}$ concentration, in a $6 \mathrm{~mL} / \mathrm{kg}$ dose, following the techniques of experimental models that are described in the literature. ${ }^{13,16}$

Meconium was collected on the first day of life from normal term newborns where there was no history of maternal drug exposure and no urine contamination. The samples were packed into plastic collectors and kept unfrozen at $3{ }^{\circ} \mathrm{C}$ until acceptance by the investigator. Initially, the meconium was diluted in distilled water to a concentration of $25 \mathrm{mg} / \mathrm{mL}$ and was filtered to remove particles with a diameter greater than $3 \mathrm{~mm}$, aiming at eliminating the likely effect of obstructing the airways. Afterwards, the material was lyophilized. For meconium administration to the animals, the lyophilized meconium was reconstituted with a physiological saline solution to a 65 $\mathrm{mg} / \mathrm{mL}$ concentration. ${ }^{13,16,20}$

\section{Surfactant preparation}

The surfactant used in this study was produced and supplied by Instituto Butantan in São Paulo at a 25 $\mathrm{mg}$ lipid/mL concentration. The surfactant was obtained by maceration of porcine lung and was composed of phospholipids (phosphatidylcholine, phosphatidylethanolamine, phosphatidylglycerol, phosphatidylinositol, phosphatidylserine, and sphingomyelin) and 2 proteins (SP-B and SPC).$^{21}$ The product was kept unfrozen at $3^{\circ} \mathrm{C}$ until the time of administration; all samples were obtained from the same production lot.

This surfactant had been tested and proven effective in a previous study that used the experimental model of premature newborn rabbits with respiratory distress syndrome. ${ }^{22}$

\section{Experimental animals}

\section{Birth and ventilation beginning}

Term newborn rabbits from New Zealand White breed were used. They were obtained through a cesarean at 30 days gestation. Initially, the pregnant rabbits were sedated with an intramuscular application of ketamine and acepromazine solution $(10 \mathrm{mg} / \mathrm{kg}$ and $0.1 \mathrm{mg} / \mathrm{kg}$ ), followed by spinal anesthesia with $2 \mathrm{~mL}$ of a 1:1 (vol:vol) solution of $2 \%$ lidocaine and $0.5 \%$ bupivacaine. After the laparotomy and hysterotomy over a thermal mattress, the newborn rabbits were delivered, and the membranes and the placentas were removed.

After being dried and weighed, each newborn rabbit was anesthetized with an intraperitoneal administration of ketamine-acepromazine $(10 \mathrm{mg} /$ $\mathrm{kg}-0.1 \mathrm{mg} / \mathrm{kg}$ ) and submitted to tracheostomy with a metal cannula (internal diameter of $1 \mathrm{~mm}$ ). Animals that weighed under $35 \mathrm{~g}$ were excluded from the study. Before the beginning of ventilation, endotracheal administration of meconium $(65 \mathrm{mg} / \mathrm{mL})$, in a $6 \mathrm{~mL} / \mathrm{kg}$ dose, and manual ventilation with a self-inflating bag for about 10 seconds were performed. Afterwards, the animals received pancuronium 
through an intraperitoneal route (20 $\mu \mathrm{g})$ so there would be no spontaneous respiration. The mechanical respira-

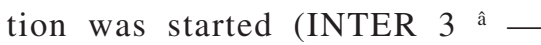
Intermed-São Paulo) using a respiratory rate (RR) of 60 cycles/min with an inspired oxygen concentration $\left(\mathrm{FiO}_{2}\right)$ of 1.0 and a peak inspiratory pressure (PIP) necessary to acquire a tidal volume of $8 \mathrm{~mL} / \mathrm{kg}$ and positive end-expiratory pressure (PEEP) of $3 \mathrm{~cm}$ $\mathrm{H}_{2} \mathrm{O}$. Controlled assisted ventilation was continued for a 25-minute period.

The animals were randomized into 4 groups as follows: having no meconium aspiration (Control); having meconium aspiration, without exogenous surfactant treatment (MEC); having meconium aspiration with 100 $\mathrm{mg} / \mathrm{kg}$ surfactant treatment (S100); having meconium aspiration with 200 $\mathrm{mg} / \mathrm{kg}$ surfactant treatment (S200). All treatments were administered in the $10^{\text {th }}$ minute of ventilation.

After the beginning of the ventilation, tidal volume $\left(\mathrm{V}_{\mathrm{T}}\right)$, dynamic compliance (DC), and ventilatory pressure (VP) at 5, 10, 15, 20, and 25 minutes were determined. The data were gathered with the help of a pneumotacograph (Hans Rudolph Inc. ${ }^{\circledR}$ ) attached to a pressure transducer $\left(\right.$ Validyne $\left.^{\circledR}\right)$, and they were analyzed with the help of specific software (Lab View Data Aquisition ${ }^{\circledR}$ - National Instruments). Ventilatory pressure was considered to be the difference between the PIP and the PEEP, and dynamic compliance ( $\mathrm{mL} / \mathrm{cm} \mathrm{H}_{2} \mathrm{O} \cdot \mathrm{kg}$ ) was calculated through the division of $\mathrm{V}_{\mathrm{T}}(\mathrm{mL} / \mathrm{kg})$ by $\mathrm{VP}\left(\mathrm{cm} \mathrm{H}_{2} \mathrm{O}\right)$. Adjustment of the PIP was performed as necessary in order to maintain a target $\mathrm{V}_{\mathrm{T}}$ of $8 \mathrm{~mL} / \mathrm{kg}$ at $30 \mathrm{sec}$ onds before every measurement.

The animals that did not present a reduction of their lung compliance values equal to or greater than $30 \%$ compared with the Control group and those that presented signs of pneumothorax at any time during the study were excluded.
Animal sacrifice and lung manipulation

After 25 minutes of ventilation, the animals were deeply sedated with intraperitoneal sodium pentobarbital (25 $\mathrm{mg} / \mathrm{kg}$ ), followed by tracheal clamping for 5 minutes to measure the pulmonary pressure-volume curve (P-V curve).

After the sacrifice of the animals with an intrathecal injection of $0.5 \mathrm{ml}$ of $2 \%$ lidocaine, the P-V curve measurement was performed, measuring the lung volume 30 seconds after insufflation, at increments of $5 \mathrm{~cm} \mathrm{H_{2 }} \mathrm{O}$ until a maximum pressure of $30 \mathrm{~cm} \mathrm{H}_{2} \mathrm{O}$ was achieved, followed by the deflation of the lung at 5 $\mathrm{cm} \mathrm{H}_{2} \mathrm{O}$ decreased to $0 \mathrm{~cm} \mathrm{H}_{2} \mathrm{O}$.

After the P-V curve was measured, the lungs were inflated to $30 \mathrm{~cm} \mathrm{H}_{2} \mathrm{O}$ pressure for 1 minute, followed by a decrease of the pressure to $10 \mathrm{~cm} \mathrm{H}_{2} \mathrm{O}$ and tracheal clamping. The animals were dissected, with removal of the lung and heart as a unit. The pulmonary tissue for histology was obtained using a standardized procedure for determining a representative area, as determined from a pilot study, selecting tissue slices ( $5 \mathrm{~mm}$ thickness) from pulmonary regions with better macroscopic evidence of the presence of meconium. The fragments were fixed in a $10 \%$ formalin solution for a minimum period of 24 hours. The tissue was then processed in paraffin and stained with hematoxylin and eosin.

\section{Histopathology}

The histopathology was done using optical microscopy, aiming at studying areas of atelectasis or pulmonary hyperinsufflation. For this, the number of alveolar intercepts was de- termined through a grid with 50 lines and 100 points with a known size, where 10 fields per slide under 200x magnification were counted. For comparison between the groups, the mean linear intercept $(\mathrm{Lm})$ from the number of intercepts per field and the lung tissue distortion index (SDI) were determined. The Lm was calculated from the relationship between the length of the lines and the number of intercepts (crossing of the lines with the alveolar septum), and the SDI was determined from the standard deviation of the means of Lm in each group.

\section{Statistical analysis}

The comparison of the means between the groups was done by 2-way analysis of variance with the StudentNewman-Keuls test as the discriminatory posttest, adopting a significance level of $5 \%$. When the data did not present the prerequisite of a normal distribution and the similar variances, the Kruskal-Wallis 1-way analysis of rank test was used as a test for nonparametric data. The comparison among proportions was done using the chi-square test.

\section{RESULTS}

Twenty females were used, with a total of 50 neonates. There were 4 animals that were excluded due to pneumothorax, 2 animals with a birth weight under $35 \mathrm{~g}$, and 4 that did not present a decline in the lung compliance greater than $30 \%$ in relation to the Control group. The number of animals and the mean weight in each group are summarized on table 1 .

Table 1 - Number of animals and weight (mean \pm sd) for each group.

\begin{tabular}{lcl}
\hline Group & Number of animals & Weight $(\mathrm{g})$ \\
\hline Control & 9 & $40.3 \pm 3.9 *$ \\
MEC & 9 & $42.7 \pm 6.5$ \\
S100 & 9 & $37.3 \pm 2.3$ \\
S200 & 13 & $43.3 \pm 6.7$ \\
\hline
\end{tabular}

$\mathrm{P}=.069$ vs all the other groups 


\section{Respiratory mechanics}

Figures 1,2, and 3 show the animals' behavior in the first 25 minutes of mechanical ventilation regarding the tidal volume $\left(\mathrm{V}_{\mathrm{T}}\right)$, dynamic compliance, and ventilatory pressure. The $\mathrm{V}_{\mathrm{T}}$ remained stable (varying from 7.9 to $8.2 \mathrm{~mL} / \mathrm{kg}$ ) during the entire ventilation period, and there were no differences among the 4 groups (Figure 1).

The 3 groups that received meconium through an endotracheal route had a decrease in the dynamic compliance values greater than or equal to $30 \%$ compared with the animals from the Control group. The animals that were treated with exogenous surfactant showed a significant improvement of dynamic compliance compared with the MEC group, whereas there were no differences regarding the surfactant dose used (Figure 2). Similar results were found regarding the ventilatory pressure, with higher pressures in animals from the MEC group (Figure 3).

The P-V curves are shown in Figure 4. The untreated animals (MEC group) needed a higher pressure to start the pulmonary insufflation compared with the animals from the S200 group and achieved a lower volume with a maximum pressure of $30 \mathrm{~cm}$ $\mathrm{H}_{2} \mathrm{O}$ when compared with the control and treated groups. In the pulmonary deflation phase at pressures of 20 and $25 \mathrm{~cm} \mathrm{H}_{2} \mathrm{O}$, the $\mathrm{S} 100$ and $\mathrm{S} 200$ groups had better alveolar stability, or rather a smaller tendency to collapse compared with the MEC group. Nevertheless, at a pressure of $5 \mathrm{~cm} \mathrm{H}_{2} \mathrm{O}$, the MEC group had a higher volume than the groups that were treated with surfactant. Differences between the S100 and S200 groups were not observed.

\section{Histopathology}

Histology was performed on a minimum sample of 6 animals in each group. The lungs of the animals from the MEC group presented a pattern of heterogeneous pulmonary aeration with the focus of atelectasis distributed between normal and hyperinsufflated areas, while both groups that were

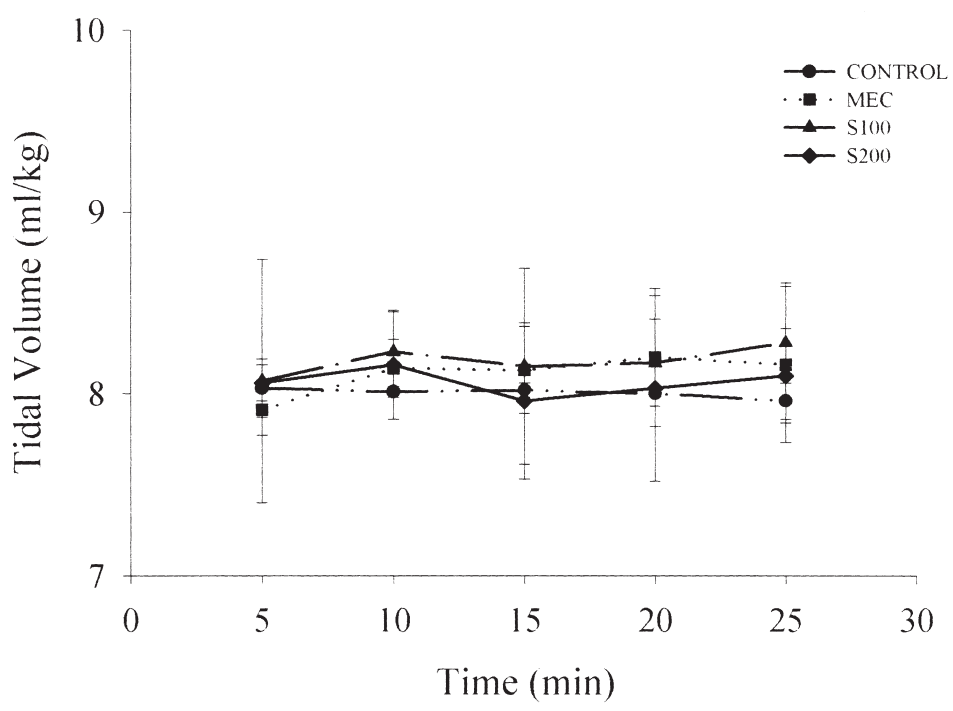

Figure 1 - Values of tidal volume $\left(\mathrm{V}_{\mathrm{T}}\right)$ of the 4 groups during the 25 minutes of ventilation. The $\mathrm{V}_{\mathrm{T}}$ varied from 7.9 to $8.2 \mathrm{~mL} / \mathrm{kg}$, having no differences among the 4 groups.

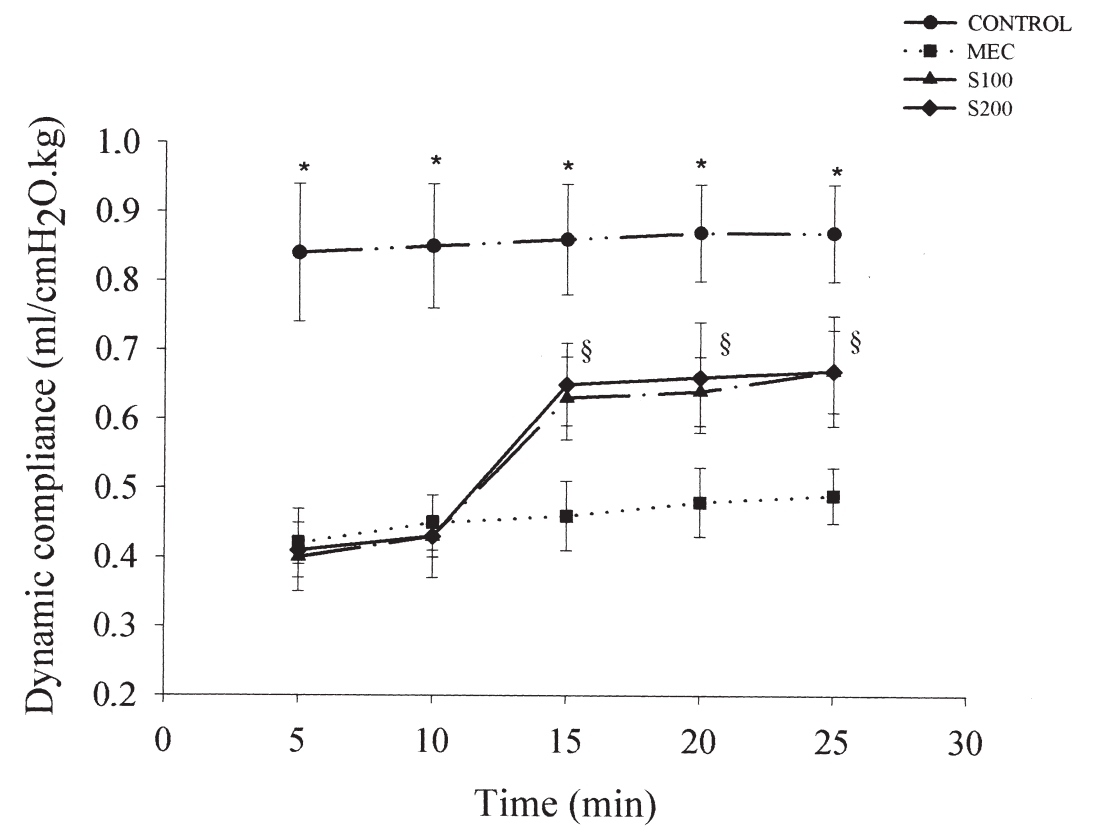

${ }^{*} P<0.001$ vs all the groups

$\S P<0.001$ vs MEC

Figure 2 - Values of dynamic lung compliance (DC). After the administration of surfactant (100 or $200 \mathrm{mg} / \mathrm{kg}$ ) with 10 minutes of ventilation, there was a significant improvement of both treated groups in relation to the MEC group, independent of the dose used. 


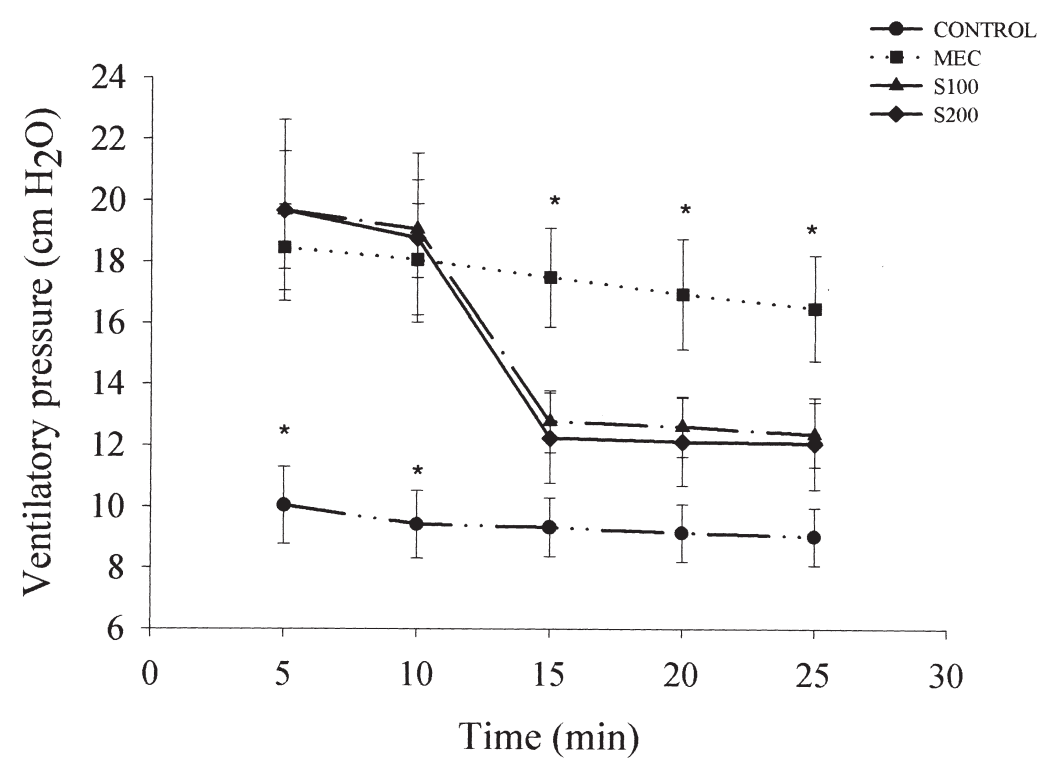

${ }^{*} P<0.001$ vs all the groups

Figure 3 - Values of ventilatory pressure (VP). After the administration of surfactant (100 or $200 \mathrm{mg} / \mathrm{kg}$ ) with 10 minutes of ventilation, there was a significant decrease of the VP values necessary for maintaining the target $\mathrm{V}_{\mathrm{T}}$ for the 2 treated groups compared with the MEC group, independent of the dose used.

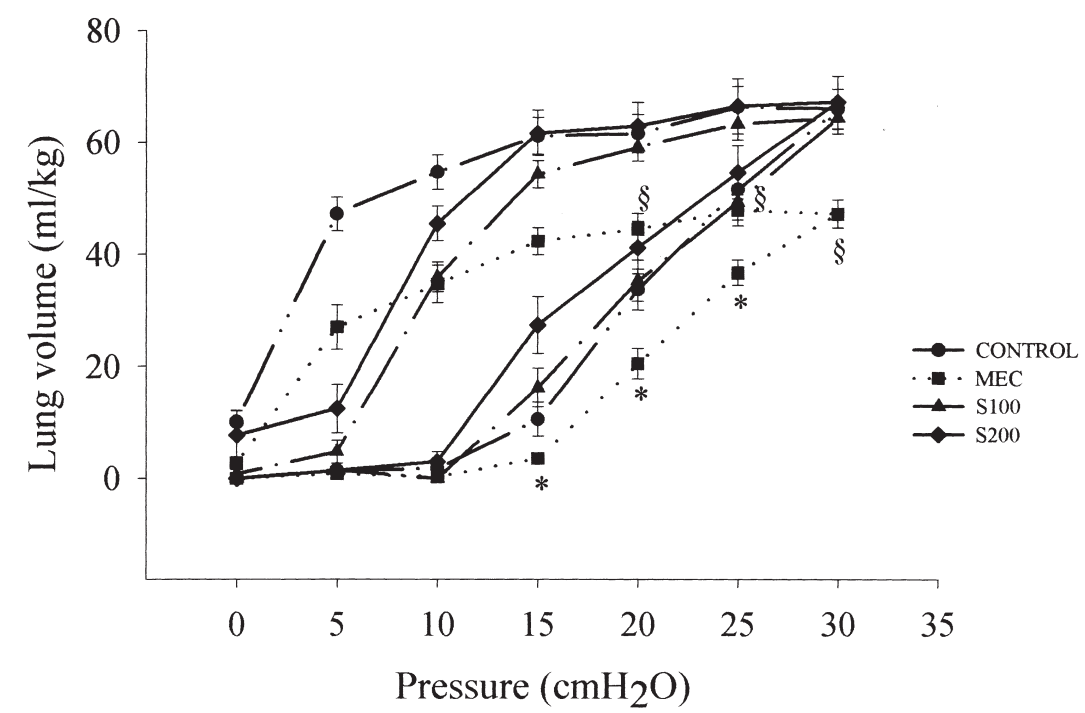

$* P<0.05$ vs $\mathrm{S} 200$

$\S P<0.05$ MEC vs outros grupos

Figure 4 - Values of the pulmonary volume-pressure $(\mathrm{P}-\mathrm{V})$ curve. The animals of the MEC group needed a more elevated pressure to initiate the pulmonary insufflation compared with the Control and S200 groups. Under the maximum pressure of $30 \mathrm{~cm} \mathrm{H}_{2} \mathrm{O}$, the animals of the Control, S100, and S200 groups had a greater pulmonary volume, maintaining this standard during the entire deflation phase until a pressure of $20 \mathrm{~cm} \mathrm{H}_{2} \mathrm{O}$ was reached. There was no difference between the 2 groups treated with exogenous surfactant.
Lm from the Control and MEC groups were similar, and both had a statistically significant difference in relation to the S100 and S200 groups. Analyzing only the SDI, both treated groups were similar to the Control group, with these 3 groups differing from the MEC group.

\section{DISCUSSION}

Several publications have demonstrated the meconium-inactivating effect on surfactants ${ }^{7,12,20,23-25}$. However, there are a small number of investigations that studied the effects of replacement therapy using exogenous surfactants in animal models with MAS. The majority of these studies were published by the same group of researchers, which justifies the performance of more experimental research with this approach. ${ }^{15,16,26}$ Sun et al. ${ }^{13}$ developed an animal model to quantify, under well-defined experimental conditions, the effects of meconium aspiration on the pulmonary function of term newborn rabbits and later the effects of the treatment with surfactant of rabbits with MAS. ${ }^{16}$ We chose to reproduce this model because the monitoring of the pulmonary mechanic proprieties is possible. Additionally, rabbits are low-cost small animals that are easy to handle and reproduce, with a large number of offspring per brood. ${ }^{27}$

We followed the previously published meconium administration and preparation techniques in which the meconium was initially diluted and filtered, eliminating the larger particles of 3 micrometers or more. This procedure allowed the most homogeneous distribution of meconium, avoided obstruction of airways, and restrained main effect of the meconium to that of surfactant inactivation. ${ }^{13,16}$ Since previous experiments had demonstrated that there was no difference in the use 


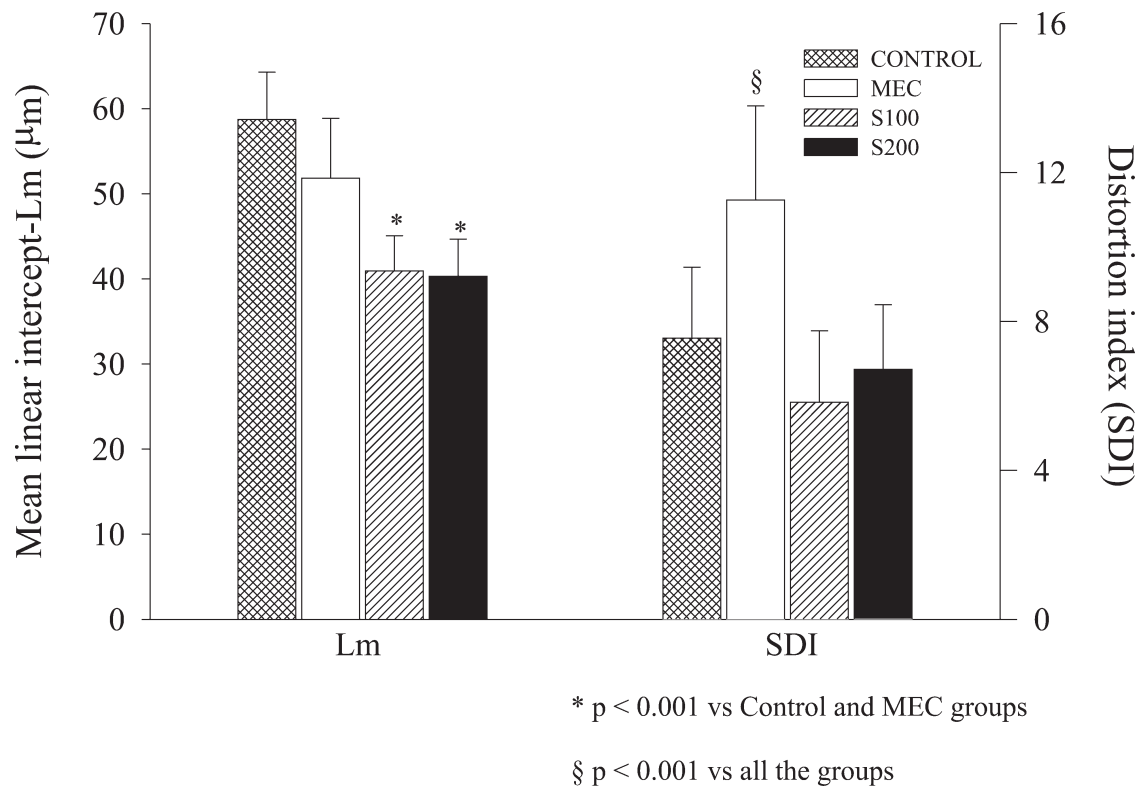

Figure 5 - Values of the mean linear intercept $(\mathrm{Lm})$ to the left and the lung tissue distortion index (SDI) to the right. The groups that received surfactant (100 or $200 \mathrm{mg} / \mathrm{kg}$ ) had lower values of Lm and SDI, which denote a lower alveolar diameter and a more homogeneous pulmonary expansion pattern for the treated groups compared with the MEC group.

of concentrations of 65 or $130 \mathrm{mg} / \mathrm{mL}$ regarding decreases in the lung compliance, ${ }^{13,16}$ we chose the lower concentration $(65 \mathrm{mg} / \mathrm{mL})$ because of its greater ease of administration through tracheal cannulae with reduced internal diameters. The meconium volume that was used was the necessary one for induction of MAS in adult rats with a decrease of the lung compliance values greater than or equal to $30 \%$, which was determined as being from 4 to $6 \mathrm{~mL} / \mathrm{kg}^{26}$

There is not a standardization of ventilatory parameters in the literature to be used in animal models. ${ }^{27}$ Sun et al. ${ }^{16}$ used in newborn rabbits a RR of 40 inspirations per minute, PEEP of 0 , $\mathrm{FiO}_{2}$ of 1.0, and a 1:1 relationship I:E; adjusting the PIP every 15 minutes to achieve a pre-established $\mathrm{V}_{\mathrm{T}}$ of 8 to 10 $\mathrm{mL} / \mathrm{kg}$. Subsequently, these authors used the same $\mathrm{RR}$ and $\mathrm{FiO}_{2}$ parameters in adult rats, but at this time, they fixed the PIP and PEEP initially at 10 and 0 $\mathrm{cm} \mathrm{H}_{2} \mathrm{O}$ with a subsequent increase to 28 and $5 \mathrm{~cm} \mathrm{H}_{2} \mathrm{O}$ respectively, and variations in the $\mathrm{V}_{\mathrm{T}}$ were observed; they concluded that higher levels of PIP are needed to assure $\mathrm{a} \mathrm{V}_{\mathrm{T}}$ greater than $6 \mathrm{~mL} / \mathrm{kg}$, which is essential for the survival of the animals under these conditions. ${ }^{13,26}$ In another study with rats, ${ }^{15}$ a new manner of ventilation was proposed to mimic clinical practice, adjusting the ventilator parameters according to the monitoring of the arterial gases. We have based our study on these studies and also on data from clinical practice, fixing the $\mathrm{V}_{\mathrm{T}}$ at 8 $\mathrm{mL} / \mathrm{kg}$ and making adjustments in the PIP values as needed to assure homogeneous ventilation among all the studied animals.

The ventilation time was fixed at 25 minutes, which was ample time for the surfactant inactivation to occur. ${ }^{15,16,20,26}$ This fact has been confirmed by our results, where it was observed that immediately after receiving meconium in the trachea, the animals had a decrease in lung compliance with a higher necessity of ventilatory pressure compared with controls. Additionally, ventilation time greater than 30 minutes is asso- ciated with a high prevalence of pneumothorax and an elevated mortality in this animal model ${ }^{28}$.

Herting et al. ${ }^{25}$ compared the inhibitory effects of meconium on several types of exogenous surfactants and demonstrated that the several surfactants react in a different way to inhibition by meconium, depending on the apoprotein type and concentration. In our experiment, we used a surfactant that was produced with a Brazilian technology by Instituto Butantan, the effectiveness of which had already been demonstrated for SDR treatment in premature rabbits. ${ }^{22}$ Additionally, a pilot study (unpublished data) demonstrated that this surfactant, whenever administered to rabbits with MAS, behaves similarly to Curosurf $^{\text {ò }}$, a preparation available on the international market. The study of the effectiveness of this surfactant is part of a research line that is being developed in our laboratory.

The surfactant dose used in the experiments varied between 100 to 200 $\mathrm{mg} / \mathrm{kg} \cdot{ }^{13,15,16}$ Use of these dosages was derived from knowledge that in MAS an inactivation of the exogenous surfactant also occurs; therefore, the better option would be the higher dose. Sun et al. ${ }^{26}$ treated rats with MAS with a modified porcine surfactant at doses of 100 and $200 \mathrm{mg} / \mathrm{kg}$, and the best results were obtained with the higher dose, however, in this experiment, tracheal aspiration was performed at predetermined moments, which might have caused misinterpretation of the results, because of the possible surfactant removal during the aspiration

In our study, we opted for comparing 2 doses (100 and $200 \mathrm{mg} / \mathrm{kg}$ ), since the initial hypothesis was that the higher dose would be more effective and previous studies had not analyzed this comparison. The inclusion of the Control group allowed the evaluation of the magnitude of the 
worsening of the respiratory mechanism after the installation of MAS, as well as the magnitude of the improvement after treatment with exogenous surfactant.

The 4 groups were ventilated in a homogeneous manner as demonstrated by the results of $\mathrm{V}_{\mathrm{T}}$ measurements, which remained without differences between the 4 groups during the entire ventilation period.

The animals with MAS had significant improvement in values of both lung compliance and ventilatory pressures after treatment with surfactant, independent of the dose used, but they did not attain the results of the Control group. Regarding pre-treatment compared with final ventilation values, there was a mean increase of $56 \%$ in the values of lung compliance and a mean reduction of $35 \%$ of the P-V values. Our results are in accord to those of Sun et al. ${ }^{16}$ where the posttreatment mean lung compliance improvement was of $31 \%$ in the groups of rabbits with MAS that had received $200 \mathrm{mg} / \mathrm{kg}$ of surfactant when compared with untreated animals. In a following study, these same authors used dosages of 100 and $200 \mathrm{mg} / \mathrm{kg}$ for the treatment of MAS in adult rats and concluded that there was an increase of lung compliance as well as an improvement in the $\mathrm{PaO}_{2}$ values of both treated groups. Even though that study was performed with a different experimental model, the compliance values after 30 minutes of ventilation were comparable to those in our study $(0.67 \pm 0.08$ and $0.65 \pm 0.15 \mathrm{~mL} / \mathrm{cm}$ $\mathrm{H}_{2} \mathrm{O} \cdot \mathrm{kg}$ respectively). These effects were only sustained in animals that received the higher dose, a finding that was observed at longer times of ventilation in that experiment, which was extended to 210 minutes. ${ }^{26}$ The study by Sun et al. ${ }^{15}$, also in adult rats with MAS, compared the immediate and delayed administration of surfactant at a dose of $200 \mathrm{mg} / \mathrm{kg}$. Their results demonstrated that lower values of ventilatory pressure were required for the attainment of the target values for $\mathrm{PaO}_{2}, \mathrm{PaCO}_{2}$ and $\mathrm{pH}$ for the treated animals, independent of the time of administration, compared with the group without treatment. The results of these last 2 studies suggest that the beneficial effects for the treatment of MAS occur with the use of high doses of surfactant. However, in our study, there was no difference between the 2 doses, but the sustained effect could not be evaluated due to the ventilation time of 25 minutes used.

In the evaluation of static lung compliance from the P-V curve, we observed that the beginning pulmonary pressure was higher for the group without treatment only in relation to the group of animals that were treated with $200 \mathrm{mg} / \mathrm{kg}$ of surfactant. This behavior remained during the entire pulmonary insufflation phase. However, at the maximum pressure of 30 $\mathrm{cm}_{2} \mathrm{O}$ and during the pulmonary deflation phase until reaching a pressure of $20 \mathrm{~cm} \mathrm{H} \mathrm{H}_{2} \mathrm{O}$, both treated groups presented higher pulmonary volumes than the untreated animals. Unexpectedly, we obtained a higher pulmonary value in the MAS group at the deflation pressure of $5 \mathrm{~cm} \mathrm{H}_{2} \mathrm{O}$, which may be explained by a possible obstruction mechanism caused by a greater amount of viscous pulmonary liquid present in this group, impeding the exit of air. This effect may not have been noticeable at the higher pressures; it could only be observed low pressures, since the surface tension of this liquid is elevated because of the surfactant deficiency, as occurs for ani- mals models with respiratory distress syndrome. ${ }^{29}$

The results of the pulmonary mechanics measurements were in accord with the findings of the histopathology. Histology revealed that the group of treated animals had a lower mean Lm and a greater homogeneity of the pulmonary expansion pattern with fewer areas of atelectasis and hyperinsufflation when compared with the group without treatment, which was demonstrated through the calculation of the lung tissue distortion index. This index detects changes in the tissue morphology and is performed to evaluate the atelectasis and hyperinsufflation pattern or the field-by-field variation of alveolar size. ${ }^{30,31}$ Our results are comparable to the histological findings by Sun et al. ${ }^{15,16,26}$, in which surfactant treatment caused an increase in the alveolar volume with fewer areas of atelectasis, with a reduction of the lung tissue distortion index after treatment with surfactant.

The present study has shown an improvement of the lung compliance following surfactant therapy for MAS that is independent of the surfactant dose used. Our results reinforce the idea that the qualitative deficiency of surfactant is an important event in MAS physiopathology, arguing favorably for surfactant replacement therapy for newborns with this illness, which might reduce the inherent risks of mechanical ventilation by reducing the required ventilatory pressure.

\section{ACKNOWLEDGEMENTS}

To Professors Isaias Raw and Flávia Kubrusly of the Butantan Institute, São Paulo/SP, Brazil, for supplying the surfactant utilized in this study. 
LYRA JC e col. Estudo dos efeitos de diferentes doses de surfactante exógeno para o tratamento da síndrome de aspiração de mecônio em coelhos recém-nascidos. Rev. Hosp. Clín. Fac. Med. S. Paulo 58(3):104-112, 2004.

OBJETIVO: Avaliar os efeitos de duas diferentes doses de surfactante exógeno sobre a mecânica pulmonar e sobre a regularidade da expansão do parênquima pulmonar em coelhos recém-nascidos.

MÉTODO: Coelhos recém-nascidos foram traqueostomizados e randomizados em quatro grupos de estudo: grupo-Controle, sem aspiração de mecônio; grupo MEC, com aspiração de mecônio e sem tratamento com surfactante exógeno; grupos S100 e
S200, ambos com aspiração de mecônio e tratados respectivamente com 100 e $200 \mathrm{mg} / \mathrm{kg}$ de surfactante exógeno (produzido e fornecido pelo Instituto Butantan). Os animais dos 4 grupos foram ventilados por 25 minutos. A mecânica pulmonar foi avaliada a partir dos valores de complacência dinâmica, pressão ventilatória, volumecorrente e volume

pulmonar máximo (curva P-V). A análise histológica foi feita calculando-se o diâmetro alveolar médio (Lm) e o índice de distorção através do desvio padrão do Lm. Utilizou-se ANOVA One Way com a =0,05.

RESULTADOS: Após 25 minutos de ventilação, os valores de complacência dinâmica $\left(\mathrm{ml} / \mathrm{cm} \mathrm{H}_{2} \mathrm{O} . \mathrm{kg}\right)$ foram:

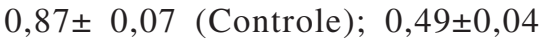

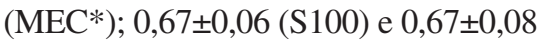

(S200) e de pressão ventilatória (cm $\mathrm{H}_{2} \mathrm{O}$ ): 9,0 0,9 (Controle); 16,5 $\pm 1,7$

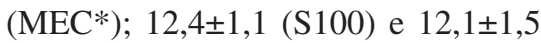
(S200). Ambos os grupos tratados tiveram padrão de expansão do parênquima mais homogêneo em relação aos animais não tratados: índice de distorção de 7,5 $\pm 1,9$ (Controle); 11,3 $\pm 2,5$ (MEC*); 5,8 ${ }^{*} 1,9$ (S100) e 6,7 $\pm 1,7$ (S200) $(* p<0,05$ vs outros grupos).

CONCLUSÕES: Animais tratados com surfactante mostraram melhora significativa da mecânica pulmonar e maior homogeneidade do padrão de expansão pulmonar comparados ao grupo não tratado. Não houve influência das doses de surfactante utilizadas.

UNITERMOS: Mecônio. Surfactante exógeno. Recém-nascido. Modelo animal. Mecânica pulmonar.

\section{REFERENCES}

1. Wiswell TE, Fuloria M. Management of meconium-stained amniotic fluid. Clinics Perinatol 1999; 26 (3): 659-68.

2. Cleary GM, Wiswell TE. Meconium-stained amniotic fluid and the meconium aspiration syndrome. Pediatr Clin North Am 1998; 45 (3): 511-29.

3. Wiswell TE, Bent RC. Meconium staining and the meconium aspiration syndrome. Ped Clin North Am 1993; 40 (5): 95580.

4. Wiswell TE, Foster NH, Slayter MV, Hachey WE. Management of a piglet model of the meconium aspiration syndrome with high frequency or conventional ventilation. Am Journal of Dis Child. 1992; 146: 1287-93.

5. Soukka HR, Ahotupa M, Ruutu M, Kaapa PO. Meconium stimulates neutrophil oxidative burst. Am J Perinatol 2002; 19(5): $279-84$

6. Brown Dl, Pattishal EN. Other uses of surfactant. Clinics Perinatol 1993; 20 (4): 761-89.

7. Cleary GM, Antunes MJ, Ciesielka DA, Higgins ST, Spitzer AR, Chander A. Exudative lung injury is associated with decreased levels of surfactant proteins in a rat model of meconium aspiration. Pediatrics 1997; 100 (6): 998-1003.

8. Johansson J, Gustafsson M, Palmblad M, Zaltash S, Robertson B, Curstedt T. Synthetic surfactant protein analogues. Biol Neonate 1998; 74 (suppl 1): 9-14.
9. Kattwinkel J. Surfactant: Evolving issues. Clinics Perinatol 1998; 25 (1): $17-32$

10. Wiswell TE. Expanded uses of surfactant therapy. Clinics Perinatol 2001; 28 (3): 695-711.

11. Davey AM, Becker JD, Davis JM. Meconium aspiration syndrome: physiological and inflammatory changes in a newborn piglet model. Pediatr Pulmonol 1993; 16: 101-8.

12. Holm BA, Enhorning G, Notter RH. A biophysical mechanism by which plasma proteins inhibit lung surfactant activity. Chem Phys Lipids 1988; 49: 49-55.

13. Sun B, Cursted T, Robertson B. Surfactant inhibition in experimental meconium aspiration. Acta Paediatr 1993; 82: $182-9$.

14. Halliday HL, Speer CP, Robertson B. Treatment of severe meconium aspiration syndrome with porcine surfactant. Eur J Pediatr 1996; 155: 1047-51.

15. Sun B, Cursted T, Robertson B.Exogenous surfactant improves ventilation efficiency and alveolar expansion in rats with meconium aspiration. Am J Respir Crit Care Med 1996; 154: 764-70.

16. Sun B, Curstedt T, Song GW, Robertson B. Surfactant improves lung function and morphology in newborn rabbits with meconium aspiration. Biol Neonate 1993; 63: 96-104. 
17. Findlay RD, Taeusch HW, Walter FJ. Surfactant replacement therapy for meconium aspiration syndrome. Pediatrics 1996; 97 (1): 48-52

18. Khammash H, Perlman M, Wojtulewicz J, Dunn M. Surfactant therapy in full-term neonates with severe respiratory failure. Pediatrics. 1993; 92 (1): 135-9.

19. Lotze A, Mitchell BR, Bulas DI, Zola EM, Shalwitz RA, Gunkel JH. Multicenter study of surfactant (beractant) use in the treatment of term infants with severe respiratory failure. J Pediatr 1998; 132 (1): 40-7.

20. Moses D, Holm BA, Spitale P, Liu MY, Enhorning G. Inhibition of pulmonary surfactant function by meconium. Am J Obstet Gynecol 1991; 164 (2): 477-81.

21. Kubrusly FS, Netto SI, Iourtov V, Raw I, Araujo PS. A natural surfactant from pig lungs. Biotechnology Letters 2000; 22: 1251-3.

22. Arcas RM, Chang CY, Proença RM, Reys AMA, Lyra JC, Gibeli $\mathrm{MAC}$, et al. In vivo testing of a new low cost surfactant compared with Survanta using the preterm rabbit model: Lung mechanics and morphometric analysis. Pediatr Res 2000; 47 (4): $386 \mathrm{~A}$.

23. Bae CW, Takahashi A, Chida S, Sasaki M. Morphology and function of pulmonary surfactant inhibited by meconium. Pediatr Res 1998; 44 (2): 187-91.

24. Dargaville PA, South M, Mc Dougall. Surfactant and surfactant inhibitors in meconium aspiration syndrome. J Pediatr 2001; 138 (1): 113-15.
25. Herting E, Rauprich P, Stichtenoth G, Walter G, Johansson J, Robertson B. Resistance of different surfactant preparations to inactivation by meconium. Pediatric Res. 2001; 50 (1): 44-9.

26. Sun B, Herting E, Curstedt T, Robertson B. Exogenous surfactant improves lung compliance and oxygenation in adult rats with meconium aspiration. J Appl Physiol 1994; 77 (4): 1961-71.

27. Arcas RM Estudo das propriedades mecânicas do sistema respiratório, com análise morfométrica e histopatológica, num modelo experimental em coelhos recém-nascidos de termo e pré-termo, submetidos à ventilação mecânica. São Paulo, 1997. 114p. Dissertação (Mestrado) - Faculdade de Medicina, Universidade de São Paulo.

28. Sun B, Kobayashi T, Cursted T, Grossmann G, Robertson B. Application of a new ventilator-multi-plethysmograph system for testing efficacy of surfactant replacement in newborn rabbits. Eur Respir J 1991; 4: 364-70.

29. Enhörning G, Robertson B Lung expansion in the premature rabbit fetus after tracheal deposition of surfactant. Pediatrics 1972; 50 (1): 58-66.

30. Dolhnikoff M, Sakae RS, Saldiva PH, Martins MA. Morphological determinants of peripheral lung mechanical changes induced by capsaicin. Respiration Physiology 1997; 108: 63-72.

31. Eidelman DH, Lei M, Ghezzo Rh. Morphometry of methacholineinduced bronchoconstriction in the rat. J Appl Physiol 1993; 75: 1702-10. 